\title{
Een teks - meerdere betekenisse: Hoe lees ons die Bybel?
}

\author{
Ernest van Eck \\ Departement Nuwe-Testamentiese Wetenskap \\ Universiteit van Pretoria
}

\begin{abstract}
One text - multiple meanings: How do we read the Bible?

This article discusses three ways of reading the Bible that are evident in the current theological debate in South Africa: a fundamentalist, foundationalist and critical reading. $A$ brief description and evaluation of the three reading strategies are given. It is indicated that a fundamentalist reading of the Bible essentially operates with a canon in the canon, and a foundationalist reading with a canon outside the canon. A critical reading, which roots can be traced back to the Reformation, is put forward as possibly a more responsible way of reading the Biblical text, especially since it takes cognizance of the historical and cultural distance between text and reader. It is argued that readers who take this "differentness" seriously, are enabled to read the Bible afresh and anew, especially in terms of some burning ethical questions of our day. Attention is also given to a critical reading of metaphorical language of the Bible.
\end{abstract}

\section{INLEIDENDE OPMERKINGS}

Gelowiges in die Christelike tradisie glo dat die Bybel God se Woord is, die Boek van die kerk, en riglyn vir 'n verantwoordelike lewe voor God. Met hierdie stelling sal ons almal saamstem. Wanneer dit egter kom by die vraag oor hoe die Boek van die kerk inhoud gee aan 'n verantwoordelike lewe voor God, loop die paaie uiteen. Die rede hiervoor is eenvoudig: ons almal lees die Bybel nie op dieselfde manier nie.

'n Kort voëlvlug oor die geskiedenis van die lees van die Bybel ${ }^{1}$ toon aan dat 'n verskillende lees van die Bybel, selfs deur gelowiges behorende tot

\footnotetext{
${ }^{1}$ In die kort beskrywing wat volg is veral gebruik gemaak van McKim (1998), Van Aarde (2005), Smit (2006:9-110) en Thiselton (2007).
} 


\section{Een teks - meerdere betekenisse: Hoe lees ons die Bybel?}

dieselfde tydsgewrig, nie nuut is nie. Inteendeel. Reeds in die vroegste periode van kerk ( $2^{\mathrm{e}}$ eeu $\mathrm{nC}$ ) loop die paaie in hierdie verband uiteen. Aanvanklik het die vroegste Christene die "Bybel"² by wyse van allegorie en tipologie gelees in 'n poging om die hele Bybel (insluitend die Ou Testament) as praktiese en alledaagse rigsnoer vir die Christelike lewe te eerbiedig en toe te pas (bv Tertullianus [160-220 nC]). In die $2^{\text {de }}$ eeu ontstaan daar skole van eksegese wat elkeen 'n eie benadering tot die Bybel openbaar: in Aleksandrië in Egipte (in navolging van Philo) lê Klemens van Aleksandrië (150-216 nC) en Origenes (185-254 nC) klem op 'n allegoriese en geestelike interpretasie van die Bybel. In Antiogië (in Sirië) lê figure soos Theodorus van Mopsuestia (350-428 nC) en Johannes Chrysostomus (354-407 nC) weer klem op 'n letterlike en historiese lees van die Bybel. En in Hippo (vandag se Algerië) poog Augustinus (354-430), in sy De doctrina Christiana, om die twee bogenoemde verklaringsmetodes met mekaar te verbind deur klem te lê op enersyds die tekenleer (semiotiek) en andersyds die geestelike sleutel van die liefde as skopus van al die geskrifte van die Bybel.

In die Middeleeue vind die lees van die Bybel veral plaas in die kloosters, katedraal-skole en Middeleeuse universiteite. In die kloosters word 'n geestelike lees (lectio divina, letterlik "Goddelike lees") van die Bybel beoefen (bestaande uit die drie stappe van grammatika, meditasie en gebed) wat mettertyd kulmineer in die hermeneutiek van die bekende "viervoudige Skrifsin" (elke gedeelte in die Bybel het 'n viervoudige betekenis, te wete 'n letterlike, allegoriese, morele en anagogiese). ${ }^{3}$ In die katedraalskole word 'n skolastiese teologie ontwikkel as reaksie op die lectio divina van die kloosterdom. Hierdie skolastiese lees van die Bybel het onder andere die volgende ingesluit: deur die gebruikmaking van glosses is die Bybelse dokumente so oorgeskryf dat dit later die vorm van kommentare begin aanneem het, onderrig het by wyse van disputasie (argumentvoering) plaasgevind (die meditasie van die lectio divina is dus deur die openbare proses van argument, dialektiek en ondervraging vervang), die Vulgaat word van genommerde hoofstukke voorsien (circa 1205), en Bybelse inhoude word by wyse van temas sistematies en logies georden (vgl bv Petrus Lombardus

\footnotetext{
${ }^{2}$ Uiteraard was daar nog nie ' $n$ Bybel in die $2^{\text {de }}$ eeu nie, aangesien die kanon nog nie vasgestel was nie. Soos dit uit die kanongeskiedenis blyk, was daar egter van vroeg af 'n korpus geskrifte was as gesaghebbend beskou is ( $\mathrm{vgl}$ bv die Kanon van Muratori wat $200 \mathrm{nC}$ gedateer word).

${ }^{3}$ Die letterlike betekenis van ' $n$ gedeelte is die inligting wat daarin verskaf word (bv die godsdiens van oud-Israel), die allegoriese betekenis verwys na die leerstellige of Christologiese implikasies van die betrokke gedeelte, die morele betekenis verskaf etiese riglyne vir die Christelike lewe, en die anagogiese betekenis verwys na die beloftes van verlossing, hoop en ewige heil wat in die betrokke gedeelte geïmpliseer word (kyk Smit 2006:27). Van die invloedrykste uitleggers wat die Bybel op hierdie wyse gelees het was Gregorius die Grote (540-604 nC) en Beda die Eerbiedwaardige (673-735 nC).
} 
[1100-1160] se Sententiae). Mettertyd het laasgenoemde daartoe gelei dat die lees van die Bybel (die sacra pagina - heilige bladsye) plek begin maak het vir die gebruik van die Bybel (die sacra doctrina - die heilige leerstukke). Wat die Middeleeuse universiteite betref, het die lees (of dan nie lees!) van die Bybel 'n nog ander pad geloop. Aan hierdie universiteite was die fokus 'n soort algemene studie (bv 'n bestudering van die klassieke filosofiese tradisies van Plato of Aristoteles) as voorbereiding vir 'n latere studie in die teologie, 'n fokus wat die lees en bestudering van die Bybel op die agtergrond geskuif het. Hierdie fokus het aanleiding gegee tot die stigting van die Franciskaanse en Dominikaanse ordes in die $13^{\text {de }}$ eeu. In 'n poging om hierdie wanbalans te herstel, beweeg genoemde ordes terug na 'n letterlike lees van die evangelies met die oog om die prediking van die evangelie te bevorder. Die ontstaan van hierdie ordes het verskeie gevolge gehad: verskeie groepe binne die kerk het eie opleidingsinrigtings, skole, seminaries, fakulteite en universiteite op die been gebring. Postilles (met die oog op die prediking) het die lig gesien, en die vraag wie die gesag het om die Bybel uit lê (die amptelike kerk en die Ordes, of ook ander), het 'n brandpunt geword.

As uitvloeisel van die Renaissance (wat die Westerse mens bevry het van diepliggende bygeloof, vooroordeel en veral allerlei gesagsinstansies en maghebbers; kyk Smit 2006:38) bring die Hervorming of Reformasie van die $16^{\text {de }}$ eeu 'n radikale breuk wat die lees van die Bybel betref. Met die slagspreuk ad fontes (terug na die bronne) het die Reformatore teruggekeer na 'n lees van die Bybelse geskrifte self. Daar is gefokus op 'n intensiewe bestudering van byvoorbeeld die Griekse manuskripte van die Nuwe Testament, verskeie vertalings van die Bybel het die lig gesien, en 'n onderskeid is getref tussen enersyds die Bybelse boodskap en andersyds die lering van die (Roomse) kerk. Fokus is geplaas op die letterlike sin of betekenis van die teks van die Bybel ( $\mathrm{d}$ w s, nie die geestelike of allegoriese betekenis nie). Hierdie fokus het daartoe gelei het dat baie ernstig gevra is na die oorspronklike bedoeling van die skrywers van die Bybelse dokumente. Volgens die Reformatore het die Bybelskrywers van alle moontlike retoriese tegnieke (bv die moontlikheid van taal, verhale, gelykenisse, argumente, aanmanings, appèlle, metafore) gebruik om die Woord van God op skrif te stel. Wat meer spesifiek die Bybelse hermeneutiek van die Reformatore betref, is hierbo reeds verwys na hulle soeke na die oorspronklike bedoeling van die skrywers van die Bybelse dokumente. In hierdie soeke is gebruik gemaak van 'n grammaties-historiese (filologies-histories) metode van eksegese - 'n eksegetiese benadering wat uitdrukking gegee het aan hulle oortuiging dat die trefkrag van die Bybel geleë is in die letterlike betekenis van die teks in sy historiese konteks.

Hierdie wyse van Bybellees is bo alle twyfel een van die belangrikste nalatenskappe van die Reformasie, te wete die (bewustelike) inagneming van 
die historiese afstand tussen die Bybelse teks en die leser ${ }^{4}$ - 'n nalatenskap wat 'n histories-kritiese ondersoek van die Bybelse teks impliseer.

Calvyn se hermeneutiek kan kortliks as voorbeeld van bogenoemde eksegetiese benadering dien. Calvyn fokus in sy lees van die Bybel op die letterlike en grammatiese betekenis van die Bybelteks, en onderskei tussen die betekenis en betekenisvolheid van die Bybel. Die betekenis van die Bybel verwys na die letterlike, literêre en historiese betekenis van die teks (sy sg simplex sensus - die eenvoudige sin of betekenis). Om die letterlike betekenis van die teks te ontsluit, oordeel Calvyn dat die destydse historiese konteks van die skrywer ernstig opgeneem moet word, aangesien die betekenis van die woorde in die teks, hulle grammatiese samehang, genre en kommunikasie onder andere bepaal word deur die historiese omstandighede van die skrywer. Calvyn stel dit verder duidelik dat die leser van vandag nie die direkte (eerste) gehoor van die Bybel is nie. In sy literêre en historiese lees van die Bybelteks gee Calvyn baie noukeurig aandag aan die oorspronklike betekenis en funksie van die woorde in die teks en daarom is 'n deeglike en verantwoorde grammatiese en historiese analise van die oorspronklike tale vir hom van groot belang ${ }^{5}$.

\footnotetext{
${ }^{4}$ Boers (1979:17) beskryf hierdie insig van die Reformasie soos volg: "The Reformers ... intended to establish the Bible's authority more firmly, completely ... as the basis and norm over and against the contemporary church. That implied the rejection of the tradition of the ongoing life of the church and with it the continuity with the Bible which had been provided by it. The Bible was no longer an integral, contemporary part of the living religion but was separated from it by an intervening history, that very history of the ongoing life of the church which had previously provided continuity with the Bible. $A$ historical consciousness thus arose with the Reformation ... the Bible was not an integral, contemporaneous part of the living religion but separated from it historically. That is, Christianity could no longer think its own thoughts as if they were identical with the Bible's thoughts. It could no longer merely draw the material for its thinking from the Bible. It had to think the very thoughts of the biblical writers rather than its own and to interpret the former as they related to the contemporary life of the church, as had been done in an exemplary way by Luther and Calvin in their commentaries" (Boers 1979:17; my kursivering).

${ }^{5}$ Calvyn se kritiese ingesteldheid ten opsigte van die bestudering van die teks van die Bybel het in kort op die volgende neergekom: hy het gebruik gemaak van die beste tekste wat hy in die grondtale kon vind, die teks gekorrigeer waar nodig, 'n deeglike analise gedoen van die teks se struktuur, woorde en idiome, en die teks probeer verstaan in terme van sy historiese en kulturele konteks. Calvyn se kritiese ingesteldheid in sy benadering tot die teks van die Bybel blyk duidelik uit die volgende spesifieke voorbeelde: die taal en styl van 1 en 2 Petrus verskil so van mekaar dat die skrywer van 1 Petrus nie 2 Petrus geskryf het nie (Corpus Reformatorum 38:403); Paulus is nie die skrywer van Hebreërs nie (Torrance \& Torrance 1963:1); die intensie van die outeur kan alleen bepaal word indien die historiese en geografiese situasie van die outeur in ag geneem word (Institutes IV, xvi, xxiii); in die eksegese van 'n teksgedeelte moet daar altyd gepoog word om van die beste Griekse teks gebruik te maak (Corpus Reformatorum 59:800); die makrokonteks van 'n gedeelte is medebepalend vir die betekenis daarvan (Institutes III, xvii, xiv); en metaforiese taal in die Bybel moet nie letterlik geïnterpreteer word nie (Institutes II, viii, xvi, xviii, IV, i, iv). Calvyn was verder van mening dat die Nuwe-Testamentiese skrywers aanhalings uit die Ou Testament op so 'n wyse gesiteer het dat dit van nuwe betekenisse voorsien is, dat verskeie verse in die Nuwe Testament as glosses beskou behoort te word, en telkens gewys op oorskryffoute wat die kopieerders van die tekste van die Nuwe Testament begaan het (kyk o a Gamble 1992a, 1992b; De Long 1992:142; Nicole 1992; Puckett 1998:172-173). Op grond van bogenoemde voorbeelde is dit nie vreemd dat verskeie Bybelwetenskaplikes Calvyn beskou as die grondlegger van die moderne histories-grammatikale eksegese nie (kyk o a Puckett 1998:172; Thiselton 2007).
} 
Dit is verder interessant om te let hoe die begrippe grammatika, retoriek en genre by Calvyn gefunksioneer het. Volgens Calvyn fokus die grammatika op die detail van 'n betrokke teksgedeelte (afsonderlike fragment), en die retoriek op die wyse hoe 'n aantal afsonderlike fragmente saam funksioneer. Om laasgenoemde te verstaan, moet na die geheel (genre) gekyk word - dus nie net na wat gesê word nie, maar ook vir wie, waarom, wanneer, en met watter bedoeling in die oog. Die betekenisvolheid van die teks, aan die ander kant, het te make met dit wat die teks vir vandag se leser wil sê (die teks se sg usus of bruikbaarheid).

'n Verdere saak wat vir Calvyn van groot belang was, en hom van sy tydgenote onderskei het, was sy oortuiging dat 'n grammaties-historiese lees van die Bybel die leser daarvan "verras, oorweldig, uitdaag, ontstel, konfronteer, verbaas" (Smit 2006:51). So word die tekste in die Bybel, het hy geoordeel, vir die lesers van alle eeue en plekke, met bepaalde oortuiginge en vooronderstellings, 'n ware Gegenüber, 'n "vreemde stem van 'n ánder wat mense aanspreek".

Met bogenoemde in gedagte is dit nie moeilik om die wortels van byvoorbeeld die historiese kritiek as erfgoed van die Reformasie te sien nie. Dit geld ook vir enige ander hermeneutiese benadering of eksegetiese metode wat bewustelik die historiese afstand tussen die teks en leser, asook die genre en retoriek van 'n teks - soos die Reformasie - in ag neem. Eksegetiese benaderings en metodes soos Literarkritik, die Formgeschichte, Traditionsgeschichte, Redaktionsgeschichte, retoriese analises, poststrukturalistiese, narratologiese, sosiaal-wetenskaplike en ideologie-kritiese lees van die Bybelteks (ondersteun met 'n hermeneutiek van suspisie) is daarom ook niks anders as produkte en logiese uitvloeisels van die Reformasie nie.

Hierdie Reformatoriese tradisie en kosbare erfenis word egter tans bedreig deur bepaalde Skrifbeskouinge en praktyke van Bybellees wat vaardig is in verskeie (Reformatoriese) kerke en wat manifesteer in die handhawing van 'n outoritêre Skrifbeskouing - praktyke van Bybellees wat bogenoemde nalatenskap van die Reformasie (die verskillende kontekste wat ' $n$ rol in die Bybelleesproses speel) misken, en tog voorgee om Reformatories te wees. Dit is ironies dat die voorstanders van hierdie praktyke van Bybellees en Skrifgebruik oordeel dat net húlle Reformatories is in die lees van die Bybel (en ander nie). Wat meer is, die magspel oor wie die Bybelteks reg (mag) interpreteer, is skielik weer op die tafel - soos in die Middeleeue! 
Twee sodanige Skrifbeskouings kan breedweg as fundamentalisme en fondamentalisme getipeer word ${ }^{6}$ - twee "Reformatoriese" wyses van omgaan met die Bybelteks wat of die insigte en resultate van die Reformasie verbygaan of nie begryp nie, met ingrypende implikasies vir die teologie van die Reformatoriese kerk, die Christelike etiek en diegene vir wie of namens wie die Bybel gelees word. ${ }^{7}$

In wat volg, word 'n kort beskrywing van 'n fundamentalistiese en fondamentalistiese wyse van Bybellees gegee. Hierdie twee wyses van Bybellees word dan krities geëvalueer deur gebruik te maak van voorbeelde wat verband hou met die Christelike etiek. ${ }^{8}$ Daarna word oorbeweeg na wat as 'n kritiese lees van die Bybel beskou kan word - 'n lees van die Bybel wat in kontinuïteit wil staan met die hermeneutiese beginsels van die Reformasie. Ten slotte word kortliks aandag gegee aan 'n sinvolle en verantwoordelike omgang met die metaforiese spreke van die Bybelteks, asook dit wat die etiek van Bybellees genoem kan word.

\footnotetext{
${ }^{6}$ Genoemde twee wyses van Bybellees het duidelik tydens die laaste $\left(68^{\text {ste }}\right)$ Algemene Kerkvergadering van die Nederduitsch Hervormde Kerk van Afrika (NHKA) na vore gekom. Daar kan met reg gevra word hoe dit moontlik is in die lig van die feit dat alle predikante van die Kerk by dieselfde teologiese fakulteit opgelei word waar, eg aan die Hervormde Kerk se Reformatoriese tradisie, studente ingelei word in 'n kritiese lees van die teks - 'n Reformatoriese wyse van omgang met die Bybelteks wat uitdrukking gee aan die standpunt van die NHKA oor Skrifbeskouing soos uitgespel in die memorandum Die Bybel - God se Woord ook vir ons tyd. Gedagtes van die Kerk oor Skrifbeskouing wat voor die $66^{\text {ste }}$ Algemene Kerkvergadering gedien en aanvaar is.

${ }^{7}$ Alhoewel dit nie die fokus van hierdie bydrae is om die redes te ondersoek hoekom Reformatoriese teoloë die Bybel op 'n fundamentalistiese of fondamentalistiese wyse lees nie, kan die volgende redes sydelings genoem word: (1) die huidige postmoderne konteks het 'n behoefte na "sekerhede" en "vastighede" laat ontstaan, (2) 'n politieke konteks waarin die belewing van verlies akuut is, laat gelowiges noodwendig na "vastighede"/"sekerhede" soek, asook (3) die rol wat opvoeding, kultuur, politieke ideologie, verwysingsraamwerke, persoonlike geskiedenis, geloof en godsdiens speel in ons lees van die Bybel.

${ }^{8}$ Hierdie keuse word gemaak omdat die verskillende wyses van Bybellees (fundamentalisties, fondamentalisties en krities) tydens die $68^{\text {ste }}$ Algemene Kerkvergadering van die NHKA juis na vore gekom het in die debatte waar daar oor etiese sake (bv homoseksualiteit) gehandel is.
} 


\title{
2. WERKDEFINISIES: WAT IS FUNDAMENTALISME EN FONDAMENTALISME
}

\subsection{Fundamentalisme ${ }^{9}$}

'n Beskrywing van die begrip "fundamentalisme" is nie 'n eenvoudige aangeleentheid nie. Die definisie van James Barr is in hierdie verband welbekend en kan as vertrekpunt dien. Volgens Barr (1981:1) kom fundamentalisme neer op

(a) a very strong emphasis on the inerrancy of the Bible, the absence from it of any sort of error;

(b) a strong hostility to modern theology and to the methods, results and implications of modern critical study of the Bible;

(c) an assurance that those who do not share their religious viewpoint are not really "true Christians" at all.

'n Soortgelyke definisie word by Montsma (1999:40; kyk ook Marsden 1991; 2006:199-219) gevind: ${ }^{10}$

\begin{abstract}
Onder fundamentalisme verst ik een eigen vorm van orthodox protestantisme die 1. sterke nadruk legt op de onfeilbaarheid van de Schrift, die Gods woord niet bevat, maar is; 2 . het gezag van dit Woord van God in scherpe stelling brengt tegenover de Schriftkritiek, die uitgaat van het menslijk-feilbare karakter van de bijbel; 3. streeft naar eigen organisaties voor Schriftgetrouwe studie en getuigenis.
\end{abstract}

Ander, soos Houlden (1995:45-46), sien die basis van die fundamentalisme geleë in die aanvaarding van die antieke Bybelse kosmologie "simply because it is found and expressed in the Bible" (kyk ook Scott 2001:147-148). Van Harskamp (1999:11-20), op sy beurt weer, oordeel dat die kenmerke van die

\footnotetext{
${ }^{9}$ Dit word algemeen aanvaar dat die begrip fundamentalisme in die Christelike tradisie sy ontstaan het in evangelikaals-Protestantse kringe in ongeveer 1920 in die VSA as reaksie op die resultate van die histories-kritiese bestudering van die Bybel. Aangesien die begrip ook met godsdienstige fanatisme verbind word, is dit belangrik om daarop te let dat fundamentalisme in die onderhawige artikel nie aan laasgenoemde verbind word nie, maar aan 'n bepaalde wyse van Bybellees.

${ }^{10}$ So ook Village (2007:34), wat min of meer dieselfde beskrywing van die fundamentalisme as dié van Barr en Montsma bied: "The key beliefs that are important [to the fundamentalist] reader of the Bible include beliefs about the origin of the Bible, its inspiration, inerrancy, literal truth and authority."
} 
fundamentalisme hoofsaaklik in sosiologiese terme ${ }^{11}$ uitgedruk behoort te word: fundamentaliste is teen alles wat as modern, andersdenkend en akkommoderend gesien word. ${ }^{12}$ Volgens hom toon Christelike fundamentaliste drie gemeenskaplike eienskappe: (1) die onderskrywing van die historiese feitelikheid van gebeure/vertellings in die Bybel (veral die maagdelike geboorte van Jesus en die wonders van Jesus), die oortuiging dat die Bybel onfeilbaar is en meganies geïnspireer is, en die absolute norm vir gelowiges is, (2) 'n terugtrek vanuit die moderne kultuur na 'n eie kulturele enklawe ${ }^{13}$ waar fanatiese toewyding verwag word ('n sg "gulzige gemeenskap"), en (3) die handhawing van 'n radikaal-konserwatiewe standpunt in die openbare en politieke lewe. ${ }^{14}$

In hierdie verband kan ten slotte na Labuschagné (2000:29-33) se tipering van die fundamentalisme verwys word. Volgens Labuschagné kan die fundamentalisme as 'n afsonderlike geestelike stroming beskryf word wat onverdraagsaam staan teenoor alle andersdenkendes buite die eie groep. Tiperend van die fundamentalisme is 'n konserwatiewe, anti-liberale en anti-

\footnotetext{
${ }^{11}$ Spong (1991:5), op sy beurt weer, definieer fundamentalisme in psigologiese terme: "A major function of fundamentalist religion is to bolster deeply insecure and fearful people. This is done by justifying a way of life with all its defining prejudices. It thereby provides an appropriate and legitimate outlet for one's anger. The authority of the inerrant Bible that can be readily quoted to buttress this point of view becomes an essential ingredient to such a life. When the Bible is challenged, or relativized, the resulting anger proves the point categorically".
}

${ }^{12}$ Wat genoemde drie sake betref toon empiriese ondersoeke 'n duidelike verband aan tussen fundamentalisme en homofobie (Schwartz \& Lindley 2005:145; Altemeyer \& Hunsberger 1992:113-133), diskriminasie ten opsigte van gender-gelykheid (Kirkpatrick 1993:256-268; Helminiak 2006:173; kyk ook Ruthven 2004) en aversie in homoseksualiteit (Kirkpatrick 1993:256-268; Laythe, Finkel, Bringle \& Kirkpatrick 2002:623-635; Altmeyer 2003:17-28), 'n rasmatige/etniese bevooroordeelde ingesteldheid (Kirkpatrick 1993:256-268; Laythe, Finkel, Bringle \& Kirkpatrick 2001:1-10; 2002:623-635; Altmeyer 2003:17-28; Rowatta \& Franklin 2004:125-128), 'n sterk outoritêre ingesteldheid (Altmeyer \& Hunsberger 1992:113133; Laythe, Finkel, Bringle \& Kirkpatrick 2001:1-10; 2002:623-635), asook 'n ongenaakbare houding teenoor ander wat andersdenkend is (Applegate, Cullen, Fisher \& Vander Ven 2006:719-754). Fundamentaliste toon ook 'n gebrek aan entoesiasme wat die ekumene betref (Henry 2003).

\footnotetext{
${ }^{13}$ In hierdie verband maak Corento (2002:335) die volgende opmerking: "[M]ost 'fundamentalisms' involve special forms of identity politics, meaning, and labeling, characterized by a quest for certainty, exclusiveness, and unambiguous boundaries, where the 'Other' is the enemy demonized. It also reflects a mind-set uncompromising and antirelativist, as one response to the openness and uncertainties of a cosmopolitan world, and to chart a morally black and white path out of the gray zones of intimidating cultural and religious complexity" (kyk ook Boone 1988:7; Nagata 2004:481-498).

${ }^{14}$ Kyk in hierdie verband ook Blei (1996:30-33) wat feitlik 'n presiese definisie as die van Van Harskamp (1999:11-20) voorstaan. Blei lê net meer klem op die neiging by fundamentaliste om, volgens sy oordeel, die letterlike (meganiese) geïnspireerdheid van die Bybel te verbind aan die historiese feitlikheid van die verskillende Bybelverhale.
} 
intellektuele inslag (kyk ook Antoun 2001). Alle moderne Bybelwetenskaplike arbeid word in beginsel afgewys, die wêreldbeeld van die Bybel word gehandhaaf (wat 'n afwysing van die evolusieleer en moderne resultate oor die ouderdom van die aarde insluit as sou dit on-Bybels wees), en daar word naarstiglik vasgehou aan bepaalde selektief-gekose tyd- en kultuurgebonde kulturele opvattinge van die ou Nabye-Ooste soos die ondergeskiktheid van die vrou aan die man en die afwysing van homoseksualiteit (kyk ook Peek, Lowe \& Williams 1990:1205).

Uit bogenoemde definisies wil dit lyk of die volgende kenmerke as tipies van die fundamentalisme beskou sou kon word: ${ }^{15}$

- 'n bepaalde Skrifbeskouing wat die Bybel sien as meganies geïnspireer en daarom onfeilbaar - 'n inspirasie wat deur die Bybel self geleer word. Die Bybel is 'n heilige Godgegewe boek, en bevat nie net die woord van God nie, maar is die Woord van God. Elke letter van die Bybel is gesagvol, ook vir vandag;

- 'n letterlike lees van die Bybel sonder die inagneming van die historiese afstand tussen die leser en die teks (verskillende kontekste en wêreldbeelde);

- die Bybel is in alle opsigte histories (letterlik) waar;

- 'n vyandige ingesteldheid teenoor 'n kritiese lees van die Bybel (antiintellektuele inslag), ${ }^{16}$ en

- 'n skerp afgrensing (nie-akkommoderende ingesteldheid) teenoor ander wat anders dink.

\footnotetext{
${ }^{15}$ Met die samevatting wat volg, word nie geïmpliseer dat daar met elke aspek van die definisies wat aangebied is, saamgestem word nie. Die Reformatoriese teologie dink byvoorbeeld meer genuanseerd na oor die historisiteit van die vertellings in die Bybel nadenke wat ' $n$ bepaalde verstaan van die metaforisiteit van die Bybel insluit wat juis die historisiteit van die Bybel bevestig.

${ }^{16}$ In hierdie verband maak Smit (2006:56-57) die volgende opmerking: "Baie fundamentaliste glo juis dat die fundamentele beginsels wat hulle uit die Bybel aflei so duidelik en rasioneel is dat nie enige uitleg daarvoor nodig is nie, en hulle is dikwels oortuig dat die aandrang op hermeneutiek of verantwoordelike uitleg net 'n verskoning is om die fundamentele beginsels waaroor die Bybel so helder is, te wil ontken of verswak. Vir hulle is die Woord van God glashelder en is menslike interpretasie onnodig."
} 
Vir die doel en fokus van die onderhawige artikel (asook die konteks waarin dit aangebied word), word daar, in wat volg, van die volgende werkdefinisie uitgegaan:

Fundamentalisme, wat ook biblisisme genoem kan word, gaan uit van 'n naïewe lees (letterlike lees) van die Bybelteks, ook bekend as "the plain sense of Scripture", sonder die inagneming van die historiese afstand en kulturele verskil tussen die Bybelteks en die moderne leser. Hierdie lees van die teks word beskou as die "behoudende standpunt", en enige ander lees as "liberaal".

Bogenoemde definisie impliseer 'n spesifieke verstaan van die lesende subjek (hoe gelees word) en die objek (wat gelees word). Anders gesê: dit gee uitdrukking aan 'n bepaalde leesproses (relasie tussen subjek en objek). Gesien vanuit die gesigspunt van die lesende subjek, impliseer hierdie tipering van die fundamentalisme 'n leeshouding van "ek lees die Bybel soos dit na my toe kom" (die Bybel funksioneer dus alleen in terme van gesigs- of klankwaarde). Gesien weer vanuit die gesigshoek van die objek (teks), bestaan die teks uit die letter(s) van die teks, en niks meer as dit nie. ${ }^{17}$

\subsection{Fondamentalisme}

Soos in die geval van fundamentalisme, is 'n beskrywing van fondamentalisme (foundationalism) ook nie 'n eenvoudige saak nie. Vanuit 'n epistemologiese hoek verwys hierdie begrip na "objektiewe kennis" of "objektiewe waarhede", en word deur Burkhard (kyk Van Aarde 2008) soos volg gedefinieer: "[F]oundationalism refers to absolutely irreducible principles of knowledge and action whose truth imposes itself with irrefutable evidentiary power. They are 'first principles', since nothing can precede them, and as such they are unquestioned." Lyotard verbind weer die begrip met wat hy die "reigning Western discourse" noem, wat, volgens Levinas, totalitêre regimes soos Nazisisme en Stalinisme insluit (kyk Van Aarde 2008). Van Aarde self oordeel dat ons hier ook Amerikanisme, Afrikanistiese ChristelikNasionalisme, kapitalisme, patriargalisme, heteronormatiwisme, positivisme en historisme sou kon byvoeg. In hierdie sin, oordeel hy, verwys foundationalism na enige totalitêre sisteem, of dit nou epistemies (bv

\footnotetext{
${ }^{17}$ Matteus 5:32 ('Elkeen wat van sy vrou skei behalwe oor owerspel, maak dat sy egbreuk pleeg, en iemand wat met die geskeide vrou trou, pleeg ook egbreuk') kan hier as illustrasie dien. Wanneer hierdie teks gelees word "soos die Bybel na my toe kom" (slegs i t v die teks se gesigs- of klankwaarde) is die etiese implikasie van die teks dat iemand wat skei behalwe oor owerspel, egbreuk pleeg, en so ook iemand wat met die geskeide vrou trou. Sodanige interpretasie (en die toepassing daarvan in die eie konteks) is niks minder as ' $n$ etnosentristiese verstaan van hierdie uitspraak van Jesus nie - dit aanvaar dat aan die begrippe egbreuk, owerspel en skei (en by implikasie aan die begrippe huwelik en seksualiteit) presies dieselfde betekeniswaarde toegeken kan word soos dit in die eie konteks verstaan word.
} 
positivisme of skolastisisme) ekonomies (bv kapitalisme of sosialisme), gender (bv patriargalisme of heteronormatiwisme), polities (Nazisisme of Amerikanisme), of sosiologies (rassisme of kulturele pluralisme) van aard is. Dit is hierdie verband dat die begrip fondamentalisme ook verwys na bepaalde "metanarratiewe" wat bepaalde persone marginaliseer en, omdat hierdie "metanarratiewe" "absoluut" en "objektief" is (nooit bevraagteken word nie), die stemme van hierdie gemarginaliseerdes nie gehoor word nie (bv patriargalisme of seksisme).

Toegepas op die leesproses, kom fondamentalisme neer op 'n omgang met die Bybel met as vertrekpunt bepaalde "ewige waarhede" wat allesbepalend vir die lees en verstaan van die teks is, ewige waarhede (fondamente) wat kan bestaan uit bepaalde vooroordele, vooronderstellings of bepaalde verstaansraamwerke - fondamente wat reeds bestaan, as algemeen aanvaarbaar en ewig beskou word, en daarom nie weer gelê te word of bevraagteken te word nie. ${ }^{18}$

'n Paar voorbeelde van hierdie "ewige waarhede" wat in die leesproses van die Bybel 'n rol speel sou die volgende kon wees: Die Bybel weerspreek sigself nooit nie en is onfeilbaar; die Bybel is God se Woord en bevat nie

18 ' $n$ Gepaste voorbeeld van sodanige omgang met die Bybel is drie artikels wat Van Eck in die 1980's geskryf het om die Kairos-dokument krities te beoordeel (kyk Van Eck 1986a, 1986b, 1986c). Die skrywers van die Kairos-dokument het drie teologieë geïdentifiseer wat deel van die teologiese toneel in die 1980's in Suid-Afrika was (Kairos Theologians 1986). Die eerste was 'n staatsteologie: "the theology of the South African apartheid State (and its church-based substantiation), which is simply the theological justification of the status quo with its racism, capitalism and totalitarianism. It blesses injustice, canonises the will of the powerful and reduces the poor to passivity, obedience and apathy" (Kairos Theologians 1986:3; vgl ook West 2008:1). Die tweede was 'n bepaalde kerkteologie "[which was - EvE] in a limited, guarded, and cautious way critical of apartheid. Its criticism, however, is superficial and counter-productive because instead of engaging in an in-depth analysis of the signs of our times, it relies upon a few stock ideas derived from Christian tradition and then uncritically and repeatedly applies them to our situation" (Kairos Theologians 1986:9; my beklemtoning). Die derde teologie, ' $n$ profetiese teologie, was "a theology that speaks to the particular circumstances of this crisis, a response that does not give the impression of sitting on the fence but is clearly and unambiguously taking a stand" (West 2008:1; kyk ook Kairos Theologians 1986:18). Geïnformeer deur 'n bepaalde kulturele gesitueerdheid en die politieke denke van die Afrikaner in die 1980's (as sou dit dié 'waarheid' wees), asook die klakkelose navolging van die breë denke in die kerk in daardie tyd (lees 'ons is reg en hulle nie'), het Van Eck toe gemeen dat die profetiese teologie se oproep tot sosiale geregtigheid in Suid-Afrika Marxisties van aard sou wees. Die tragiese hiervan is dat hy daarom die ideologiese gedrewenheid en propaganda van die destydse heersende politieke leiding misgekyk en bevryding beskou het as blote bevryding uit sonde. Hy het die kerk se onbetrokkenheid ten opsigte van sosiale ongeregtigheid teologies probeer regverdig en geoordeel dat die Kairosdokument bydra tot 'n verdere polarisering van die Suid-Afrikaanse samelewing. Vandag oordeel Van Eck dat hierdie kritiek inderdaad "superficial" en "counter-productive" was inderdaad gebaseer op "a few stock ideas derived from Christian tradition and then uncritically and repeatedly applied them to our situation" (kyk weer Kairos Theologians 1986:9). In kort was hierdie kritiek op die Kairos-dokument niks anders as die beskerming van eie belange en die goedkeuring van 'n uitbuitende politieke bestel nie. Bepaalde vooroordele, vooronderstellings en verstaansraamwerke (lees 'fondamente' of 'ewige waarhede') het by die skrywer so 'n groot rol gespeel dat 'n bevraagtekening van die sosiale onreg, ook deur die kerk gepleeg, ongelukkig vanweë die tydsgees nie besef is nie. 
alleen God se woord nie; die kerk het 'n kultuuropdrag en daarom is die kerk kultuur- en volksgebonde; vroue is minderwaardig ten opsigte van mans; God maak nie homoseksuele mense nie; jy kan nie iemand uit ' $n$ ander kultuur vertrou nie; en alle rasse is nie gelyk voor God nie. Smit (2006:75) sê oor hierdie "fondamente" die volgende:

[D]ie vooroordele, die vooronderstellings, die verstaansraamwerke, waarmee ons na die Bybel kom as ons dit lees en daarna luister, word op baie komplekse, ingewikkelde en dikwels onbewuste maniere gevorm. Ons lees nie so onbevange as wat ons dikwels dink nie. Inteendeel, ons lees die Bybel as mense wat reeds diepgaande gestempel is deur bepaalde lewenskontekste, sowel psigiese as sosiaal; deur die omgewings en tradisies waaruit ons kom; deur ons verwagtings en belange en die redes waarom ons lees; deur die gemeenskappe waarbinne ons maniere en konvensies van lees aangeleer het - amptelik, bewus en gesaghebbend, maar ook nie-amptelik, onbewus en diep verborge, maar nie daarom noodwendig van geringer invloed nie. ${ }^{19}$

(Smit 2006:75)

Volgens Snyman (2007:13), wat oor Bybellees in die Suid-Afrikaanse kerklike konteks reflekteer, is een so 'n "fondament" die bevestiging van 'n bepaalde magsposisie, en word die Bybel op so 'n wyse gelees dat bepaalde persone (in hierdie geval die blanke middelklas heteroseksuele man) se mag nie ingeperk word nie, terwyl 'n groep mense van die besluitnemingsproses uitgesluit word. Hy noem die volgende drie voorbeelde:

- Wat Apartheid betref, het persone van Europese afkoms die Bybel só gelees dat hulle velkleur in die sosiale orde beskerm is;

- wat die posisie van vroue in sommige kerke betref, het sommige kerklike vergaderings (sinode, ring, konferensie) tot dusver nog as 'n groep mans opgetree wat die Bybel interpreteer asof die skepping van man en vrou 'n sekere magsorde daargestel het; en

- wat homoseksualiteit betref, is dit mense met 'n heteroseksuele oriëntering wat die sosiale orde seksueel definieer en homoseksualiteit as afwyking daarstel.

Die indruk wat telkens in bogenoemde drie voorbeelde gewek word, oordeel Snyman, is die bevestiging van die magsposisie van 'n sekere groep persone

\footnotetext{
${ }^{19}$ Kyk weer voetnoot 18.
} 
en die bevestiging van 'n aantal "fondamente" wat as ewig en waar aanvaar word.

Met bogenoemde beskrywing van 'n fondamentalistiese teks word nie gepretendeer dat 'n kritiese lees van die teks nie ook van bepaalde "fondamente" uitgaan nie (bv die oortuiging dat daar 'n historiese en kulturele afstand tussen die Bybelteks en die moderne leser is). Die verskil is egter dat 'n kritiese lees van die teks genoemde uitgangspunt nie as 'n "ewige waarheid" of "onveranderde beginsel" sien nie, en daarom oop is om enige uitgangspunt of vooronderstelling onder die vergrootglas by wyse van 'n openbare debat te plaas. 'n Kritiese lees van die teks sien waarheid daarom ook as 'n sosiale en nie-finale aangeleentheid.

'n Laaste opmerking: uit bogenoemde beskrywing van 'n fondamentalistiese lees van die Bybel is dit duidelik dat daar bepaalde raakpunte tussen 'n fundamentalistiese en fondamentalistiese lees van die Bybel bestaan. Dit is inderdaad ook so dat 'n fondamentalistiese lees van die Bybel in die meeste gevalle voorkom by diegene wat sterk ontken dat hulle fundamentalisties is, maar in praktyk met 'n "gesofistikeerde" fundamentalisme werk. Tog is daar 'n verskil tussen genoemde twee leesmetodes wat juis in die onderhawige bydrae beklemtoon wil word: waar 'n fundamentalistiese lees van die Bybel opereer met 'n kanon in die kanon ( $\mathrm{d}$ w $\mathrm{s}$, met 'n seleksie van tekste in die Bybel; opereer 'n fondamentalistiese lees van die Bybel met 'n kanon buite die kanon (die lees van die Bybel vanuit 'n onkritiese en soms onbewuste sosiaal-gekondisioneerde beginsel). Hierdie verskil (en begrippe) word hieronder breedvoerig verduidelik.

\section{FUNDAMENTALISME EN FONDAMENTALISME KRITIES BESKOU}

\section{1 'n Fundamentalistiese lees van die Skrif draai vas}

'n Fundamentalistiese lees van die Bybel draai vas, en kan alleen oorleef deur met ' $n$ kanon in die kanon ${ }^{20}$ te opereer. Hierdie kategoriese stelling kan begrond word deur die volgende etiese uitsprake in die Bybel vanuit 'n fundamentalistiese hoek te lees ( $\mathrm{d}$ w s, 'n letterlike lees van die Bybelteks sonder die inagneming van die historiese afstand en kulturele verskil tussen

\footnotetext{
${ }^{20}$ Die begrip "kanon in die kanon", vir sover dit vasgestel kan word, is die eerste keer deur Alexander Schweizer in 1863 gebruik en kan op verskillende sake dui. Eerstens kan dit op 'n verkleinde kanon dui (bv Marsion), tweedens op die beginsel wat die wese van kanonisiteit bepaal (Semler), en derdens op die sleutel vir die regte Skrifuitleg (bv Luther en Käsemann; kyk Du Toit 1977:182). Pelser weer is van oordeel dat die begrip kanon in die kanon verwys na die gebruik in die kerk om in sy teologie op die outentieke briewe van Paulus en die vier evangelies (en in 'n mate ook Handelinge) te konsentreer (Pelser 1988:399). In die onderhawige artikel word die begrip kanon in die kanon, soos mettergaan aangetoon sal word, verstaan as 'n wyse van Bybellees wat selektief (op grond van beginsels wat nie altyd bepaalbaar is nie) met tekste in die Bybel omgaan.
} 
die Bybelteks en die moderne leser). Die volgende morele/etiese eise in die Ou en Nuwe Testament word as voorbeelde gebruik:

- 'n Vrou wat nie swanger kan raak nie mag haar slavin aan haar man gee om 'n kind te verwek wat dan as haar eie beskou kan word (Gen 16:1-2). 'n Man mag dus meer as een vrou hê (Gen 4:23-24; 26:34; Deut 17:17; 1 Kon 11:1-3; 1 Sam 1:1-2; Eks 21:10-11; Deut 22:28-29; Jes 50:1; Jer 2:2; Eseg 16:8; Spr 12:4; 18:22; 19:14; 31:10-31; Ps 128:3; Jes 3:25; 4:1), maar mag nie met 'n ma en dogter gelyktydig getroud wees nie (Lev 20:14);

- 'n Kind wie sy pa of ma slaan of vloek moet doodgemaak word (Eks 21:15, $17)$, en 'n persoon wat die Naam van die Here oneerbiedig gebruik, moet die doodstraf kry (Lev 24:16). Dit geld ook vir 'n man wat egbreuk pleeg met 'n vrou van 'n medeburger (Lev 20:10).

- Wanneer twee mans stry en die een slaan die ander met 'n klip of die vuis sonder om te dood, is dit aanvaarbaar (Eks 21:18-19);

- Jy mag nie 'n homoseksuele verhouding hê nie (Lev 18:22). Twee mans wat 'n homoseksuele verhouding het, moet doodgemaak word (Lev 20:13);

- Jy mag nie geld teen rente uitleen nie (Deut 23:19);

- Jy mag nie met gewigte werk wat nou sus en dan so is nie (Deut 25:13);

- Wanneer twee mans baklei, en een se vrou kom help en gryp die man wat haar man slaan aan sy geslagsorgane, moet haar hand afgekap word (Deut 25:11);

- Seksuele gasvryheid ('n man wat sy vrou of dogters aanbied as "onderhandelingsmiddele" met die oog op bv politieke of ander voordeel) is aanvaarbaar (Gen 19:8; 20:2; 34:1-10).

- Elkeen wat van sy vrou skei, behalwe oor owerspel, maak dat sy egbreuk pleeg, en elkeen wat met 'n geskeide vrou trou, pleeg egbreuk (Matt 19:9);

- As iemand se hand hom van God afvallig laat word, moet hy sy hand afkap (Mark 9:43);

- Jy mag nie 'n eed aflê nie (Matt 5:34); 
- As iemand na My toe kom, kan hy nie my dissipel wees nie tensy hy afstand doen van sy eie vader en moeder en vrou en kinders, en broers en susters (Luk 14:26); en

- Dit is nie betaamlik vir ' $n$ vrou om sonder iets op haar kop in die erediens tot God te bid nie (1 Kor 11:13). Vrouens moet in die byeenkomste van die Christelike gemeente stilbly, want hulle word nie toegelaat om te praat nie (1 Kor 14:34).

Hoe word bogenoemde morele opdragte deur gelowiges in ons tyd toegepas? Op een van drie wyses: Sommige van hierdie etiese opdragte word doodgewoon geïgnoreer: kinders wat hulle ouers vloek of slaan word nie doodgemaak nie, ook nie diegene wie die Naam van die Here oneerbiedig gebruik of die man en vrou wat egbreuk pleeg nie. Dit is nie vir ons aanvaarbaar dat iemand 'n ander met 'n klip of die vuis slaan net solank die een wat geslaan word nie sterf nie, en wanneer dit mag gebeur dat twee mans baklei, en een se vrou kom help en gryp die man wat haar man slaan aan sy geslagsorgane, kap ons nie die vrou se hand af nie. Ook kap ons nie ' $n$ hand af wat sonde doen nie. Ook verwag ons nie van vrouens om met 'n hoed op die kop te aanbid of in die gemeente stil te bly nie, en ons is volgelinge van Christus sonder om afstand van ons families te doen.

In ander gevalle weer, doen ons presies soos die Bybel van ons vra: Gewigte wat nou sus en dan so is word deur ons as onaanvaarbaar beskou, want dit is bedrog. En homoseksualiteit is 'n sonde, want die Bybel sê immers so. Maar al sê die Bybel so, maak ons nie homoseksuele persone dood as gevolg van 'n homoseksuele oriëntasie nie. Verder word (seksuele) egbreuk, soos die Bybel eis, deur ons afgewys, maar egbrekers word nie gedood nie.

Ander kere weer tree ons soms presies op die teenoorgestelde wyse op as wat bogenoemde etiese eise van ons vra of toelaat om te doen: Die Bybel sê dat 'n man meer as een vrou mag hê (poligamie), ons oordeel egter dat die huwelik alleen monogaam mag wees. Mans bied nie hulle vrouens of dogters aan in terme van seksuele gasvryheid nie (prostitusering) nie, en in die geval van kinderloosheid is die goedgekeurde verwekking van 'n kind buite die huwelik vir gelowiges vanuit die Christelike tradisie 'n onaanvaarbare moontlikheid. Verder leen ons geld teen rente uit, lê dikwels 'n eed af en oordeel nie dat ' $n$ man wat met 'n geskeide vrou trou, egbreuk pleeg nie. En vrouens mag nie alleen in die Christelike gemeente praat nie, hulle mag selfs predikante wees.

Soos bo gestel, is hierdie etiese toepassing van die Bybel alleen moontlik wanneer die Bybel net op sigwaarde (fundamentalisties) geneem 
word en daar met ' $n$ kanon in die kanon as interpreterende beginsel gewerk word. Geen bewussyn van die historiese en kulturele afstand tussen teks en leser is sigbaar nie, en sodoende word bepaalde kultuurpatrone van die verre verlede tot evangelie of kanon verhef. Kultuuroordrag vind dus plaas. Meer nog: geïnformeer deur of ' $n$ eie kulturele gesitueerdheid, of ' $n$ bepaalde tradisie van interpretasie, of die handhawing van bepaalde (mags)belange, besluit die leser self watter etiese uitsprake in die Bybel geld en watter nie. ${ }^{21}$

Sodanige lees van die Bybel draai nie alleen vas nie, maar ontmagtig die aanspraak wat God se Woord op ons etiese lewens behoort te hê. In hierdie verband maak Houlden (1995:45-46) die volgende opmerking:

The fundamentalist approach is dangerous, for it is attractive to people who look to the Bible for ready answers to the problems of life. It can deceive these people, offering them interpretations that are pious but illusory. Without saying as much in so many words, fundamentalism actually invites people to a kind of intellectual suicide. It injects onto life a false certitude, for it unwittingly confuses the divine substance of the biblical message with what are in fact its human limitations.

Dit is verontrustend dat lesers wat hulleself as Reformatories tipeer, die Bybel toenemend met 'n gebrekkige of afwesige historiese bewussyn interpreteer en selektiewe etiese beginsels voorstaan - terwyl dit duidelik is (en soms self ruiterlik erken word) dat die historiese bewussyn van die Reformasie geen rol speel in hulle lees van die Bybel nie, maar eerder eietydse oriëntasie en sosiale kondisionering. Wat hierdie lesers van die Bybel nie insien nie, aldus Smit (2006:188), is dit wat die kerk van die eeue en in besonder die Hervorming wel raakgesien het, te wete dat die gesag van die Bybel deur so 'n lees juis nie gerespekteer word nie, "omdat mense juis op díe manier hulle eie uitleg kan aansien as nie langer menslike uitleg nie, maar as die boodskap en betekenis van die Bybel self. Vir die Reformasie sou so 'n opvatting uiteraard skokkend en volkome onaanvaarbaar gewees het" (Smit 2006:188189).

\subsection{Fondamentalisme bevraagteken ons belange en ideologieë}

Vooroordele, vooronderstellings, verstaansraamwerke en tradisie speel 'n rol in hoe ons die Bybel lees. Omdat genoemde sake op komplekse, ingewikkelde en dikwels onbewuste maniere gevorm word, lees ons die Bybel

\footnotetext{
${ }^{21}$ So geformuleer is dit duidelik dat ' $n$ fundamentalistiese en fondamentalistiese lees van die Bybel soms hand aan hand gaan - vandaar die oortuiging dat fondamentalisme soms niks meer as ' $n$ "sagte" vorm van fundamentalisme is nie.
} 
nie so onbevange as wat ons dikwels dink nie. Sosiale kondisionering en kulturele gesitueerdheid speel hier ook 'n besliste rol, en daarom word bepaalde oortuigings (wat ook ideologieë genoem kan word) dikwels onwetend ingespan wanneer ons met die Bybel besig is.

Hierbo is reeds na sodanige etiese "fondamente" of oortuigings verwys wat soms kritiekloos ingespan word om in ons leesproses die Bybel te ontsluit. Omdat die saak van homoseksualiteit tydens die pas afgelope Algemene Kerkvergadering van die NHKA (en ook tydens die Nasionale Sinode van die Nederduitse Gereformeerde Kerk in 2007) intense debat ontlok het, word dit hier as voorbeeld van 'n fondamentalistiese lees van die Bybel gebruik. Tydens hierdie debatte het dit duidelik geword dat sommiges wat homoseksualiteit as 'n onaanvaarbare seksuele oriëntasie beskou van die volgende vertrekpunte ("fondamente") uitgaan:

- Homoseksualiteit is per se sonde;

- God maak nie persone met 'n homoseksuele oriëntasie nie (homoseksualiteit is aangeleerde "afwykende" gedrag en nie geneties nie);

- homoseksualiteit is 'n keuse;

- homoseksuele dade is teennatuurlik en "abnormaal";

- 'n heteroseksuele oriëntasie is per se natuurlik en "normaal"; en

- daarom word dit in die Bybel veroordeel.

Die volgende navorsingsresultate oor homoseksualiteit (en dus seksualiteit) wat die afgelope tyd die lig gesien het behoort egter ten minste van bogenoemde "fondamente" (in hierdie geval genetiese predisposisie) te temper, en in sommige gevalle selfs ernstig te bevraagteken: ${ }^{22}$

- Seksualiteit soos verstaan in die Bybel en vandag verskil hemelsbreed van mekaar. Seksuele verhoudings in die Bybel weerspieël 'n patriargale wêreld waarin die vrou as 'n besitting gereken is. Wat die huwelik betref, het twee families met mekaar getrou, en nie twee individue nie. Huwelike is gereël, en alleen die vrou kon binne die huwelik egbreuk pleeg. Die man kon alleen egbreuk "buite" die huwelik pleeg. Egskeiding het 'n skeiding tussen twee families beteken, en kon net deur die man geïnisieer word. Seksuele kontak binne die huwelik was uitsluitlik gemik op prokreasie. Poligamie was 'n aanvaarde beginsel, en vir 'n bepaalde tydperk was die aanbied van 'n getroude vrou of dogters deur die man of vader in terme van seksuele gasvryheid 'n aanvaarde praktyk. Dit is ook duidelik dat die

\footnotetext{
${ }^{22}$ Opmerkings wat volg oor genoemde tekste, maak nie op volledigheid aanspraak nie. Die opmerkings wat wel gemaak word, is daarop gemik om bogenoemde "fondamente" vanuit 'n kritiese hoek te belig, en lesers van die Bybel tot nadenke te stem, insluitend die outeur.
} 
inhoud wat aan die huwelik gegee is oor tye heen, verander het. Die inkleding van die huwelik het hand aan hand gegaan met bepaalde kultuurpatrone en ideologieë oor wat volkwees beteken, en soos hierdie patrone en ideologieë verander het, het die inhoud en verstaan van die huwelik verander. Die huwelik het uitdrukking gegee aan bepaalde veranderende ideologieë ten opsigte van hoe Israel hulleself as volk, en later as die Jodedom verstaan het. Die huwelik was ondergeskik aan en in diens van hierdie volksideologieë wat met 'n patriargale verstaan van die samelewing gefunksioneer het. In hierdie patriargale samelewing was vroue en kinders gemarginaliseer. Wat homoseksualiteit in die besonder betref, kom tekste wat dit verbied, die eerste keer voor in die Joodse periode (die Tweede Tempeltydperk), dit wil sê in die tyd van Esra en Nehemia. In hierdie periode van die geskiedenis van Israel beveel Esra alle Joodse mans wat met "vreemde vroue" (nie-Israeliete) getroud is, om van hulle te skei. Kan ons hierdie tekste net so vandag van toepassing maak op ons verstaan en inkleding van die Christelike huwelik? Of moet ons dalk die Bybel anders lees (en op ander tekste konsentreer) om aan gelowiges etiese riglyne vir die Christelike huwelik te gee? En watter rol behoort Jesus se negatiewe uitsprake oor die huwelik van sy tyd in ons beskouing van die huwelik as instelling te speel (vgl Mark 10:2-12; Matt 19:3-12; kyk Van Eck 2007a:81-101; 2007b:103-128; 2007c: 481-513).

- Die Bybel bevat net sewe tekste wat oor "homoseksualiteit" handel (Gen 19:5; Rig 19:22; Lev 18:22; 20:13; Rom 1:24-27; 1 Kor 6:9; 1 Tim 1:10). ${ }^{23}$ Net een van hierdie tekste, te wete Romeine 1:26, verwys na homoseksuele verhoudings tussen vroue. Moet dit verstaan word in die lig van die feit dat die wêreld van die Bybel patriargaal was, en dit wat "vroulik" was daarom van minder belang was? Of is hierdie vraag nie ter sake nie?

- Is dit in ons interpretasie van hierdie tekste belangrik dat die woord homoseksualiteit nie in die Bybel voorkom nie? En dat Paulus heel waarskynlik nie monogame homoseksuele verhoudings, soos ons dit

\footnotetext{
${ }^{23}$ Smit (2006:85) merk tereg op dat gelowiges, op grond van hierdie sewe tekste - wat homoseksualiteit in 'n mindere of meerdere mate, of dalk glad nie, veroordeel - hoogs emosioneel voel oor homoseksualiteit en selfs bereid is om die kerk daaroor te verdeel of skeur. In dieselfde asem wemel die Bybel van tekste oor sosiale- en ekonomiese onreg daar is skaars ' $n$ deel of ' $n$ genre in die Bybel wat dit nie in die allerskerpste taal veroordeel nie - maar hieroor kom nie dieselfde, of eintlik geen, emosionaliteit na vore nie. Hierdie is syns insiens 'n merkwaardige verskynsel, veral in die lig van die feit dat diegene wat so sterk oor homoseksualiteit voel, so sterk daarteen gekant is omdat hulle die Bybelse eise wil eerbiedig en gehoorsaam. Die vraag kan met reg gevra word watter etiese eis vir lesers van die Bybel wat ekonomies verontreg en uitgebuit word en die lotgevalle van ander se selfbevoorregting is, die belangrikste sou wees?
} 
vandag aantref, geken het en homoseksualiteit nie in terme van seksuele oriëntasie verstaan het nie?

- Wat Genesis 19:5 betref, dring die mense van Sodom wat Lot se huis omsingel, by hom aan dat hulle sy kuiergaste wil "ken", 'n woord in die grondtaal wat inderdaad seksuele konnotasies het. Die Nuwe Afrikaanse Vertaling vertaal dit met "om geslagsgemeenskap te hê". Sommige ouer vertalings het egter nie so gelui nie, wat daarop dui dat die klem nie op die seksuele dade van die Sodomiete geplaas word nie, maar op ' $n$ verbreking van die destydse gasvryheidsreëls - 'n saak wat juis in Genesis 18 beklemtoon word. Hiermee saam moet onthou word dat mans in die kultuurwêreld van die Ou Testament soms hulle vyande verneder het juis deur hulle te verkrag. In die daad van verkragting sou die een wat verneder word, uiteraard die passiewe (vroulike) posisie in die geslagsdaad inneem - vandaar die vernedering omdat 'n man "vroulik" opgetree het. Dit is ook interessant dat waar die Bybel na Sodom verwys, nie gesê word dat die stad weens homoseksuele dade verwoes is nie. Dit is verder interessant om daarop te let dat Bybellesers, wat hierdie gedeelte gebruik om homoseksuele dade te veroordeel, dikwels geen woord rep oor Lot se bereidwilligheid om sy twee dogters by wyse van seksuele gasvryheid aan die mans van Sodom aan te bied in 'n poging om sy gaste te beskerm teen 'n vernedering nie, dit is, om soos vroue behandel te word. En die feit dat Lot in die vertelling deur God nogtans as regverdig verklaar word nie. Wat Rigters 19:22 betref, is die parallelle met Genesis 19:5 duidelik.

- In Levitikus 18:22 en 20:13 maan die grondteks teen mans wat met ander mans "op die bed van 'n vrou slaap". ${ }^{24}$ Hierdie verse, oordeel OuTestamentici, maak deel uit van die sogenaamde Heiligheidskodeks (Lev 17-26) waarin Israel gemaan word om anders as die omliggende heidenvolke te leef. Afgodery in die omliggende heidenvolke se vrugbaarheidskultusse het dikwels gepaard gegaan met homoseksuele gemeenskap (in die vorm van prostitusie). Om aan hierdie praktyke mee te doen, word dikwels in Levitikus as 'n "afskuwelike ding" beskryf. So ook homoseksuele dade. Is dit dus nie moontlik dat homoseksuele dade hier afgewys word omdat dit as afgodery gesien is nie?

- Dit is verder ' $n$ vraag hoe ernstig die insig opgeneem behoort te word dat tekste die produk van 'n bepaalde sosiale sisteem, dit wil sê, die produk van 'n bepaalde kultuurwêreld. Indien hierdie insig ernstig opgeneem

\footnotetext{
${ }^{24}$ Levitikus 18:22, letterlik vertaal, lui "Maar met 'n manlike persoon mag jy nie slaap op die bed van 'n vrou nie".
} 
word, kan die Nuwe Testament nie losgemaak word van die Griekse en Romeinse Umwelt nie. In die Griekse wêreld was homoseksualiteit (en biseksualiteit) 'n aanvaarbare praktyk en is deur bepaalde sosiale norme gereguleer. Jong seuns se passiewe rol in homoseksuele aktiwiteit is as deel van hulle opvoeding gesien. Pederastie, as voorbeeld, moes net nie die toekoms van jong seuns negatief beïnvloed nie, en seuns moes op 'n punt hulle passiewe rol in homoseksuele aktiwiteit met 'n aktiewe rol vervang. Vir volwasse mans was manlikheid die norm, en passiwiteit in seksuele verhoudings onaanvaarbaar. Aangesien manlikheid die norm van hierdie samelewing was, was alle vroulike seksuele aktiwiteit wat nie in diens van die man gestaan het nie, onaanvaarbaar. In die Romeinse wêreld was homoseksuele dade deur mans afgewys, veral omdat dit beteken het dat ' $n$ man 'n passiewe rol in die seksdaad moes vervul - iets wat nie vir 'n Romeinse manlike burger aanvaarbaar was nie. Tot en met die vyfde eeu is dan ook net mans wat hierdie passiewe rol vervul, gestraf. Keiser Justinius (527-565) het hierdie beskouing tot ' $n$ einde gebring deur by wyse van wetgewing alle vorme van homoseksualiteit as teennatuurlik en strafbaar voor God te verklaar. Homoseksuele dade tussen vroue is veral afgewys omdat vroue hiermee getoon het dat hulle nie mans nodig het nie - en vir mans was dit onaanvaarbaar (Cantarella 2002, in Dreyer 2008:747-750).

- Romeine 1:24-27, 1 Korintiërs 6:9 en 1 Timoteus 1:10 kan heel waarskynlik teen die agtergrond van bogenoemde ontwikkeling in die beskouing van homoseksualiteit in Grieks-Romeinse wêreld verstaan word. Dit wil lyk of Paulus homoseksuele dade afwys op grond van die feit dat dit, volgens hom, kata physin (teennatuurlik) is. Vir Paulus geld dit vir beide die malakoi (passiewe) en arsenokoitai (aktiewe) persone wat deel is van homoseksuele aktiwiteit. Waar die Grieks-Romeinse wêreld in hulle standpunt ten opsigte van homoseksualiteit manlikheid en eer as sleutel gebruik het (i t v die onderskeid tussen die malakoi en die arsenokoitai), was die sleutel vir Paulus kata physin en para physin - natuurlik of teennatuurlik. Die norm was heteroseksualiteit (as natuurlik), en daarom was alleen sodanige seksualiteit aktiwiteit aanvaarbaar. Homoseksualiteit was sonde teen God, en daarom sal die malakoi en die arsenokoitai nie deel hê aan die koninkryk nie ( 1 Kor 6:9). In 1 Timoteus 1:8-10 is heteroseksualiteit dan ook die "wet", en die arsenokoitai is diegene wat die wet oortree (Cantarella 2002, in Dreyer 2008:747-750).

- Ook die Christelike kerk het deur die eeue nie altyd dieselfde standpunt ten opsigte van homoseksualiteit gehandhaaf nie. In die vroeë Christelike kerk was die houding ten opsigte van seksualiteit aanvanklik buigsaam. 
Augustinus (354-430) was die eerste teoloog in die Christelike kerk wat seksuele verhoudings geformaliseer het, en wel in terme van verlossing. Alleen heteroseksuele persone kon gered word, en seksuele aktiwiteit in die huwelik moes uitsluitlik gerig wees op prokreasie. Seksuele kontak in die huwelik met die oog op genot was dieselfde as hoerery, 'n "onuitspreeklike sonde" (Ef 5:12), en homoseksuele kontak is afgewys omdat dit nie tot prokreasie kon lei nie (Rom 1:26-27). Seksuele kontak binne die huwelik wat nie op prokreasie gemik was nie, sowel as homoseksuele kontak, is gesien as para fusin (teennatuurlik). Hierdie standpunt van Augustinus het die weg gebaan vir Thomas Aquinas (12251274) se verstaan van die huwelik as sakrament wat verlossing bewerkstellig en as kuur kan dien teen die "vleeslike begeertes" (concupiscence) van die mens (enige vorm van seks wat nie op prokreasie gemik is nie; Cantarella 2002, in Dreyer 2008:744-745).

Bogenoemde behoort die verantwoordelike Bybelleser tot die insig te bring om telkens weer (en weer) die vooroordele, vooronderstellings, verstaansraamwerke en ingeykte tradisie ( $\mathrm{d} \mathrm{w} \mathrm{s}$, "fondamente") waarmee ons die Bybel lees, krities te bedink. Veral omdat hierdie sake op komplekse, ingewikkelde en dikwels onbewuste maniere gevorm word en ons lees van die Bybel in 'n mate bepaal waarvan ons soms nie bewus is nie.

Lees ons dalk nie soms die Bybel met 'n kanon buite die kanon as sleutel nie - iets waarteen Calvyn ons lank tevore gewaarsku het? Is heteroseksualiteit byvoorbeeld die enigste aanvaarbare norm vir die uitleef van menslike seksualiteit? As dit is, hoekom? Was dit die norm in die Christelike tradisie oor eeue heen? Is hier 'n "fondament" ter sprake wat vir ewig en altyd geldig is? Is daar iets soos 'n "ewige waarheid"? Kan ons sê dat "waarheid" deur die eeue van die Christendom heen, wanneer dit kom by bepaalde etiese aangeleenthede soos seksualiteit, altyd dieselfde gebly het? In watter mate speel ons eie kulturele gesitueerdheid 'n rol in hoe ons die Bybel lees? Is ons byvoorbeeld in staat om, wat eie kerklike bodem betref, teologie en ideologie, of teologie en politiek, van mekaar los te maak wanneer ons die Bybel lees? Watter bril(le) sit ons op wanneer ons lees? En hoekom lees ons soos ons lees? Is dit omdat ons bepaalde belange wil beskerm?

In kort: watter "fondamente" bring ons na die Bybel toe wanneer ons lees? Opereer ons in ons lees van die Bybel met bepaalde kanons buite die kanon, of nie? En wie besluit watter "kanons" is belangrik en watter nie? Watter belange kom in spel wanneer hierdie keuses gemaak word? Hoekom is die saak van seksualiteit vir ons so belangrik, maar ontbreek dieselfde passie wanneer dit kom by sake soos sosiale geregtigheid, armoede en die missio Dei-sake waaraan baie meer prominensie in die Bybel verleen word? 
Uit bogenoemde wil dit lyk of 'n fundamentalistiese lees van die Bybel besluit watter tekste is belangrik en watter nie. 'n Fondamentalistiese lees van die Bybel, daarenteen, blyk te bepaal watter waardes belangrik is en watter nie. Kan beide hierdie twee wyses van lees van die Bybel as verantwoordelik beskou word?

\section{4. 'N KRITIESE OMGANG MET DIE SKRIF}

Bybellesers (en kerke) wat ernstig omgaan met hulle Reformatoriese erfenis, het hulleself nog altyd teenoor bogenoemde twee wyses van Bybellees afgegrens deur 'n kritiese omgang met die Bybelteks voor te staan. ${ }^{25}$ 'n Kritiese omgang met die Skrif gaan van die volgende vooronderstellings uit:

- daar bestaan 'n historiese afstand tussen teks en leser (die belangrike insig van die Reformasie; kyk weer voetnoot 5). 'n Kritiese lees van die Bybel is daarom beskeie in terme van die moontlikheid om die betekenis van die Bybelteks (volledig en finaal) te ontsluit (daar bestaan dus 'n bepaalde respek vir die teks), geen lees van 'n teks word as finaal beskou nie, en ander se lees van die teks word gerespekteer (al word daarmee nie saamgestem nie);

- tekste die produk is van 'n bepaalde sosiale sisteem ('n spesifieke historiese, godsdienstige en kulturele konteks of situasie), 'n sosiale sisteem wat dikwels (en in die geval van die Bybel beslis) verskil van dié van die leser. Daar bestaan dus ook 'n kulturele afstand tussen teks en leser ${ }^{26}$; en daarom word 'n poging aangewend om 'n etnosentristiese ${ }^{27}$ of nie-kultuursensitiewe lees van die teks sover moontlik te vermy; Daar word dus bewustelik gepoog om nie kultuur tot kanon (evangelie) te verhef nie;

\footnotetext{
${ }^{25}$ Wat die NHKA betref, is hierdie kritiese ingesteldheid duidelik afleibaar in die rapport getiteld Die Bybel - God se Woord ook vir ons tyd. Gedagtes van die Kerk oor Skrifbeskouing, wat voor die $66^{\text {ste }}$ Algemene Kerkvergadering gedien het en aanvaar is as die Kerk se standpunt ten opsigte van 'n verantwoordelike omgang met die Bybel.
}

\footnotetext{
${ }^{26}$ Smit (2006:58) formuleer hierdie uitgangspunte van 'n kritiese lees van die Bybel soos volg: Kritiese lesers van die Bybel is "bewus van die historiese en kulturele afstande en verskille tussen hulleself en hulle eie tyd en die Bybelse tye en daarmee diep bewus van die historiese, menslike aard van die Bybelse geskrifte, dat hulle naamlik óók produkte was van húlle tyd en tydsgees, van die kennis en kultuur en kosmologie van hulle omgewing en tyd, met ander woorde menslike produkte van menslike historiese ontwikkelinge en prosesse".

27 'n Etnosentristiese (anakronistiese) lees van antieke tekste soos die Bybel vind plaas wanneer die leser oordeel dat die kultuur van die eie wêreld en die kultuur van die wêreld van die Bybel nie van mekaar verskil nie (die Bybelse teks word gesien as produk van die eie kultuur, of die kultuur van die Bybel en van vandag is dieselfde). Wanneer hierdie onderskeid nie in die leesproses getref word nie vind kultuuroordrag plaas, en word bepaalde kultuurpatrone tot evangelie verhef. Dit misken dus die moontlikheid dat bepaalde etiese riglyne in die Bybel die produk van 'n andersoortige kultuur is, en dus nie sonder meer vir vandag kan geld nie - juis omdat kultuurpatrone en kulturele konvensies voortdurend verander.
} 
- die teks van die Bybel is die produk van 'n hoë-konteks kultuur/samelewing ${ }^{28}$ ' $n$ eienskap wat in die proses van Bybellees in ag geneem moet word deur byvoorbeeld die gebruikmaking van antropologiese, kruis-kulturele en sosiaal-wetenskaplike modelle;

- daar word van die vooronderstelling uitgegaan dat 'n teks (dus ook die Bybelteks) wil kommunikeer, en dat hierdie kommunikasie onder andere geleë is in die wyse waarop 'n teks saamgestel (gestruktureer) is. Naas die situasie van die teks (kyk bo), word daar daarom ook erns met die strategie van die teks gemaak. In 'n poging om hierdie uitgangspunte in die proses van Bybellees in ag te neem, maak die kritiese benadering gebruik van literêre eksegese.

- in die Bybel is daar soms metaforiese taal ter sprake. Die Bybelteks word daarom ook "nie-net-letterlik" (meer-as-histories) gelees;

- omdat die Bybel saam met ander en dikwels vir ander gelees word, is 'n bepaalde etiek van Bybellees van belang; en

- etiese of morele waardes ("beginsels") wat in kontinuïteit met die Jesus$\operatorname{saak}^{29}$ (kanon agter die kanon) staan, word as sleutel geag in antwoorde op etiese vraagstukke in eie konteks (die konteks van die Bybelleser).

Bogenoemde teoretiese vertrekpunte ten opsigte van 'n kritiese lees van die Bybel is nie ' $n$ aanslag op die gesag van die Skrif nie. Inteendeel. Soos in die geval van die Reformatore het ' $n$ kritiese lees van die Bybelteks eerbied vir die Skrif in die oog. Anders as wat dikwels verstaan word, is die beslissende vraag van 'n kritiese lees van die Bybelteks nie die verhouding goddelik/menslik nie, maar worstel dit met die vraag hoe die Bybel as antieke dokument in ons moderne wêreld steeds sinvol kommunikeer (juis omdat die Bybel as gesagvol aanvaar word). In hierdie verband is die uitgesproke veronderstelling dat die gesag van die Skrif nie afhanklik is van die aanwending van 'n bepaalde metode nie. Die Skrif het gesag. Die vraag

\footnotetext{
28 "High context societies produce sketchy and impressionistic documents, leaving much to the reader's or hearer's imagination and common knowledge. Since people living in these societies believe that few things have to be spelled out, few things in fact are spelled out .... [T] he typical communication problem in high context societies is not giving people enough information, thus 'mystifying'them" (Malina 2001; my emphasis).

${ }^{29}$ Die volgende word deur die skrywer as uitdrukking van die Jesus-saak gesien: die gelykheid van alle mense voor God, die akkommodering van ander, 'n nie-seksistiese ingesteldheid, die afwys van hiërargiese magstrukture, en God se teenwoordigheid by alle mense.
} 
waarmee 'n kritiese lees van die teks dus worstel, is hoe om hierdie gesag van die Bybel op 'n verantwoordelike wyse in vandag te laat spreek. "Dit is 'n eerlike poging om die Skrif self aan die woord te stel, sodat dié gesagvol kan werk" (Van Aarde 1981:17).

\section{2 'n Kritiese omgang met die Bybel stel ons in staat om relevant en Reformatories $^{30}$ te wees}

Hoe lyk 'n kritiese lees van die Bybelteks in praktyk? In wat volg, word van die voorbeelde wat hierbo gebruik is, in die evaluering van ' $n$ fundamentalistiese lees van die Bybel (kyk weer § 3.1) aan 'n kritiese lees onderwerp. Weer eens word daar nie op volledigheid aanspraak gemaak nie, en slegs 'n aantal penstrepe getrek.

Jesus se uitspraak in Lukas 14:26 ("as iemand na My toe wil kom, kan hy nie My dissipel wees tensy hy bereid is om afstand doen van sy vader en moeder en vrou en kinders, en broers en susters nie") kan as eerste voorbeeld dien. Hierdie uitspraak van Jesus, wat 'n duidelike anti-familiale ingesteldheid toon, vind aansluiting by verskeie ander uitsprake van Jesus in die Evangelies wat dieselfde inhoud en/of strekking het: navolging van Jesus impliseer haat teenoor die eie familie (Matt 10:37-38), niemand wat ' $n$ huis, broer of suster, vader of moeder, vrou of kind ter wille van Jesus verlaat het, is nie daarvoor beloon nie (Mark 10:29-30//Luk 18:29-30//Matt 19:28-29), Jesus se familie is nie sy moeder en broers nie, maar hulle wat die wil van die Vader doen (Mark 3:32-35//Luk 8:20-21//Matt 12:47-50), Jesus het nie gekom om vrede te bring nie, maar om families te verdeel (Luk 12:51-53//Matt 10:3436), en vir diegene wat Jesus volg, is daar nie tyd om eers 'n vader te gaan begrawe en Jesus dan te kom volg nie (Luk 9:57-60//Matt 8:18-22; kyk Van Eck 2007c:481-513). In 'n poging om hierdie skerp uitsprake van Jesus te verstaan, sal 'n kritiese leser van hierdie tekste poog om die bepaalde historiese, godsdienstige en kulturele konteks (genoem situasie) van hierdie uitsprake in ag te neem, te wete die patriargale sisteem van die eerste eeu 'n patriargale sisteem wat vroue as besittings in 'n man se wêreld beskou het en die outoriteit van die man as normaal beskou het, met resultaat die marginalisering van vroue en kinders. Gelees teen hierdie sosiale konvensie van die eerste eeu is dit waarteen Jesus in opstand in bogenoemde verse gekom het, en nie die familie per se nie, maar die patriargale sisteem wat 'n bepaalde verstaan van die gesin in stand hou. Omdat Jesus se "nuwe familie" juis op grond van ander beginsels funksioneer (bv die akkommodering van alle mense, nie-seksisties en anti-hiërargies), sal die vorige "familie" (patriargale sisteem) versaak moet word om deel van die nuwe familie te kan word (d w s, om Jesus te volg).

\footnotetext{
${ }^{30}$ In die konteks van die NHKA sou die word "Hervormd" hier ook gepas wees.
} 
'n Tweede voorbeeld: Jesus se uitspraak in Matteus 19:9, te wete dat 'n man wat van sy vrou skei, behalwe oor owerspel, maak dat sy egbreuk pleeg en elkeen wat met 'n geskeide vrou trou egbreuk pleeg, is vanuit ' $n$ fundamentalistiese lees van hierdie teks verdoemend vir gelowige huweliksmaats wat om ander redes as owerspel (bv $t \mathrm{w} v$ beide partye se emosionele oorlewing en menswees) skei, asook vir huweliksmaats wat hulleself in ' $n$ tweede huwelik bevind. ' $n$ Kritiese lees van hierdie teks sal egter die volgende in berekening bring: Jesus se uitspraak is 'n antwoord op die vrae van die Fariseërs (kyk Matt 9:3 en 7). Hierdie vrae van die Fariseërs word heel waarskynlik gestel in die lig van Deuteronomium 24:1-2, op grond waarvan die gee van 'n skeibrief as 'n aanvaarbare praktyk beskou is. Die agtergrond van hierdie praktyk is die hervormings van Esra en Nehemia na die ballingskap in $587 \mathrm{vC}$, waar alle Joodse mans verplig was om van "vreemde" (nie-Israelitiese) vroue te skei waarmee hulle getroud was. Hierdie opdrag, op sy beurt weer, was die gevolg van 'n bepaalde volksideologie, te wete dat Israel nou moes hervorm tot ' $n$ heilige volk wat in 'n heilige land woon waarin net heilige nasate verwek word. Ideologie het dus huwelikstrategie bepaal - met die vrou altyd in diens (en slagoffer) van hierdie ideologie. In 'n huweliksbeskouing waarin prokreasie die oogmerk was, en manlike nasate bepalend was vir die erf van familiegrond, was situasies waarin vrouens wat nie swanger kon raak nie, hulle mans by slavinne kinders laat verwek het, of mans wat poligamie bedryf het, nie 'n vreemde verskynsel nie. En in 'n samelewing waarin die eer van die patriarg alles was, was dit nie vreemd vir vaders om hulle dogters (as besittings) te prostitueer vir politieke of ekonomiese voordeel nie.

Twee laaste voorbeelde: In 'n wêreld waarin manlikheid en eer (die skaarste middel) ten nouste met mekaar verbind was, homoseksualiteit met afgodery ('n gruwel in die oë van God) verbind is, mans wat soos vrouens optree, as skaamteloos en "onrein" beskou is (die passiewe seksmaat in die homoseksuele seksdaad), seksuele kontak alleen op prokreasie gemik was, en die stort van manlike saad wat nie prokreasie kon bewerkstellig nie, gesien is as vermorsing, is dit verstaanbaar dat homoseksuele praktyke skerp afgewys is. En in 'n wêreld waarin ouers as God se verteenwoordigers gesien is, ${ }^{31}$ en die vloek van ouers deur kinders daarom gesien is as dieselfde om God te vloek, is dit verstaanbaar dat kinders wat hierdie oortreding begaan het, swaar gestraf moes word.

\footnotetext{
${ }^{31}$ Hierdie oortuiging word deur Malina \& Rohrbaugh soos volg in woorde gebring: "[J]ust as it is God alone who determines who one's parents are, so too, it is God who 'joins together' in marriage .... Since marriages were arranged by parents, to whom one owed obedience and religious respect, God was seen to have been a party to a marriage arrangement, just as God was a party to one's birth" (Malina \& Rohrbaugh 1992:30, 240).
} 
Bogenoemde voorbeelde van 'n kritiese lees van die Bybel pretendeer nie om die enigste moontlike lees van die betrokke tekste te wees nie - dit sou immers dan nie 'n kritiese lees van die betrokke tekste wees nie! Dit poog egter wel om die historiese afstand tussen teks en leser te handhaaf (die belangrike insig van die Reformasie), die teks as produk van 'n bepaalde sosiale sisteem kultuursensitief te lees, en nie bepaalde kultuurgebruike tot kanon (evangelie) te verhef nie. Dit poog verder om aan te toon dat die etiese aansprake van die teks vir vandag (die konteks van die leser) afleibaar is van die waardes waarmee Jesus bepaalde kultuur- en godsdienspraktyke van sy tyd beoordeel het. Dit sal daarom ook skepties staan oor etiese uitsprake wat van vrouens verwag om stemloos met bedekte howe in die byeenkomste van die Christelike gemeente te sit (vgl 1 Kor 11:13; 14:34) - juis omdat hierdie tekste nie in kontinuïteit staan met dit wat as die Jesus-saak (die kanon agter die kanon) getipeer kan word nie.

'n Kritiese lees van die Bybel maak ook erns met die metaforisiteit van taal. Hier kan met enkele voorbeelde volstaan word. Geen Bybelleser sal byvoorbeeld die sewe "Ek is"-uitsprake van Jesus ${ }^{32}$ letterlik interpreteer nie nie eers diegene wat die Bybel vanuit 'n fundamentalistiese hoek lees nie. Jesus is byvoorbeeld nie 'n fisiese lig, lamp of fakkel nie, maar metafories is Hy 'n lig - soos God se mense ook nie letterlik sout is nie, maar tog sout vir die aarde moet wees (vgl Matt 5:13). Hier het ons duidelik met metaforiese taal te make wat tog nie letterlik verstaan kan word nie - daar is 'n verskil tussen "wat daar staan" (letterlik) en "wat dit wil sê" (nie-net-letterlik). 'n Verdere voorbeeld: Die vertellinge oor die geboorte van Jesus, soos beskryf deur Matteus en Lukas, open 'n rykdom van betekenisse wanneer hierdie vertellings nie alleen in terme van die bevestiging van hulle historisiteit gelees word nie, maar ook in terme van hulle metaforisiteit, dit wil sê, nie-net-letterlik (meer-as-histories). ${ }^{33}$ In so 'n lees van hierdie vertellinge kom die volgende na vore wat andersins "verborge" sou bly (kyk Borg 2006:63-69):

\footnotetext{
${ }^{32}$ In hierdie sewe uitsprake beskryf Jesus homself as die brood wat lewe gee (Joh 6:35), die lig vir die wêreld (Joh 8:12), die ingang vir die skape (Joh 10:7, 9), die goeie herder (Joh 10:11), die opstanding en die lewe (Joh 11:25), die weg en die waarheid en die lewe (Joh 14:6), en die ware wingerdstok (Joh 15:1).

${ }^{33}$ Hierdie lees van die geboorteverhale van Jesus, soos dikwels aanvaar word, beteken dus nie dat die historisiteit van hierdie vertellings bevraagteken word nie. Dit is 'n nie-net-letterlike lees van hierdie vertellings, dit wil sê, dit fokus nie enkel en alleen op die vraag van historisiteit nie (dat dit gebeur het nie), maar ook op dit wat die vertellings wil sê (wil verkondig). Anders gesê: vir 'n kritiese lees van die teks is dit nie genoeg om die dat van die vertelling te bevestig nie, dit vra ook na wat die vertelling wil kommunikeer.
} 
- Jesus is die Lig wat na die wêreld toe kom (vgl Matt 2:10; Luk 1:78-79; 2:9, 32; vgl ook Jes 9:2; 60:1-3; kyk ook Joh 1:5, 9; 9:5 waarin lig as metafoor vir redding gebruik word);

- Jesus se koms is die vervulling van 'n hoop wat in Israel geleef het (vgl Matt 1:21-23; 2:5-6, 17; Luk 1:52-55, 68-71);

- Jesus se koms na die wêreld is die werk van God (vgl in hierdie verband die verhale van Sara, Rebekka en Ragel in die Ou Testament, en Jesus se geboorte as ' $n$ intensivering van hierdie verhale);

- Jesus is die Seun van God. Alhoewel hierdie 'n deurlopende tema in al vier die evangelies is, verbind Matteus en Lukas hierdie tema uitdruklik met hulle respektiewe geboorteverhale (kyk Matt 2:13; Luk 1:32, 35); en

- Jesus, en nie keiser Augustus nie, is Koning, Redder en die Een wat vrede bring (vgl Matt wat Jesus as 'n nuwe Moses tipeer en Lk 2:10-14 as uitdrukking van tipiese anti-imperiale taal).

Indien die geboorteverhale van Jesus bloot gelees sou word met die oog op die bevestiging van die historisiteit daarvan, gaan bogenoemde metaforiese betekenis van hierdie vertellings duidelik verlore.

Ten slotte 'n paar kort opmerkings oor die etiek van Bybellees. Kritiese lesers van die Bybel hou altyd rekening met die feit dat die lees van die Bybel dikwels saam met en vir ander gelees word. Dit gaan dus hier oor die effek wat 'n bepaalde lees van die Bybel op ander het. Snyman (2007:6) noem in hierdie verband die volgende voorbeeld: Is dit byvoorbeeld genoeg om aan te toon dat Jesus se woorde "om die ander wang te draai" (Matt 5:38-39) geweld (sal) beperk? Hoe lees vroue wat in 'n (patriargale) huwelik geslaan word hierdie teks? Dalk dat hierdie lees van Matteus 5:38-39 al meer vroue (psigies) doodgemaak as wat ons kan tel? Duidelik het die wyse waarop ons die Bybel lees ' $n$ invloed op ander, ander wat dikwels die gemarginaliseerdes van ons wêreld is.

\section{SLOTOPMERKINGS}

Die Bybel is die Boek van God, die Boek van die kerk en die Boek van elke gelowige wat in die Christelike tradisie staan. Die Bybel verdien dus die nodige respek wanneer dit gelees word en die vraag wat ' $n$ verantwoordelike lees van die Bybel sou wees, is daarom van wesentlike belang.

Hierbo is betoog dat ' $n$ kritiese lees van die Bybel, as produk en voortsetting van die Reformasie (ons kosbare erfgoed), ernstig en bewustelik 


\section{Een teks - meerdere betekenisse: Hoe lees ons die Bybel?}

met bogenoemde vraag wil omgaan, sonder om te pretendeer dat elke teks van die Bybel net een interpretasie het. Dit wil juis akkommoderend met ander Bybellesers omgaan, veral diegene saam met en vir wie die Bybel gelees word. Dit erken die historiese afstand tussen die Bybel en die moderne leser, en poog, in soverre dit moontlik is, die Bybel kultuursensitief te lees.

Vanuit 'n etiese oogpunt poog dit om te waak teen die ernstige verleiding om van kultuur kanon te maak deur nie 'n bepaalde verstaan van God, tradisie en kultuur (as produkte van 'n bepaalde sosiale sisteem) in "ewige waarhede" te omskep nie. Dit oordeel verder dat alles in die Bybel nie evangelie is nie, maar in dieselfde asem dat die evangelie nêrens elders as in die Bybel gevind kan word nie.

Die kritiese lees van die Bybel is 'n eerlike poging om die Bybel self aan die woord te stel, sodat dit gesagvol kan werk. Dit poog om Bybellesers daarvan te bevry om sonder meer 'n eie verstaan van die werklikheid as "woorde van God" aan te bied: "[A critical reading of the Bible] ... offers a questioning, even disruptive intervention of the self-assurance of the present to call Christians to new faithfulness and a new understanding of what faithfulness means" (Countryman 2007:4). Of, soos Calvyn dit gestel het: 'n kritiese lees van die Bybel open die moontlikheid dat die Bybel die leser kan verras, oorweldig, uitdaag, ontstel, konfronteer en verbaas. Meer nog: in 'n kritiese lees van die Bybel ontmoet lesers van alle eeue en plekke, met bepaalde oortuiginge en vooronderstellings, 'n ware Gegenüber, 'n "vreemde stem van 'n ánder wat mense aanspreek".

\section{Literatuurverwysings}

Altmeyer, B 2003. Why do religious fundamentalists tend to be prejudiced? International Journal for the Psychology of Religion 13(1), 17-28.

Altmeyer, B \& Hunsberger, B 1992. Authoritarianism, religious fundamentalism, quest, and prejudice. International Journal for the Psychology of Religion 2(2), 113-133.

Applegate, B K et al 2006. Forgiveness and fundamentalism: Reconsidering the relationship between correctional attitudes and religion. Criminology 38(3), 719-754.

Antoun, R T 2001. Understanding fundamentalism: Christian, Islamic, and Jewish movements. Lanham, MD: Rowman Altamira.

Barr, J 1981. Fundamentalism. London: SCM.

Baum, G, Cunitz, E, Reuss, E et al (eds) 1834. Corpus Reformatorum. Braunschweig: Halle. (Series II: Ioannis Calvini, opera quae supersunt omnia - Volumes 29-87.)

Blei, K 1996. Geloven op gezag: Tussen individualisering en fundamentalisme. Zoetermeer: Uitgeverij Boekencentrum.

Boers, $\mathrm{H}$ 1979. What is New Testament theology? Philadelphia, PA: Fortress. (New Testament Series.) 
Boone, K C 1988. The Bible tells them so: The discourse of Protestant fundamentalism. New York: SUNY Press.

Borg, M J 2006. Jesus: Uncovering the life, teachings, and relevance of a religious revolutionary. New York: HarperOne.

Calvin, J 1560. Institutes of the Christian religion, Vol I-III.

Cantarella, E 2002. Bisexuality in the ancient world, tr by C Ó Cuilleanáin. New Haven, MA: Yale University Press.

Corento, T 2002. Fundamentalism as a class culture. Sociology of Religion 63(3), 335-360.

Countryman, L W 2007. Dirt, greed and sex: Sexual ethics in the New Testament and their implications for today. Philadelphia, PA: Fortress.

De Long, I H 1992. Calvin as interpreter of the Bible, in Gamble 1992:127-145.

Dreyer, Y 2008. Pastoral care and gays against the background of same-sex relationships in the Umwelt of the New Testament. HTS 64(2), 739-765.

Du Toit, A B 1977. Afdeling B: Kanoniek van die Nuwe Testament, in Roberts, J H \& Du Toit, A B (reds), Handleiding by die Nuwe Testament I: Inleiding tot die studie van die Nuwe Testament en Die Kanoniek van die Nuwe Testament, 87-103. Pretoria: NG Kerk Boekhandel.

Gamble, R C (ed) 1992. Calvin and hermeneutics. London: Garland. (Articles on Calvin and Calvinism, Volume 6.)

Gamble, R C 1992a. Brevitas et Facilitas: Toward an understanding of Calvin's hermeneutic, in Gamble 1992:33-50.

Gamble, R C 1992b. Exposition and method in Calvin, in Gamble 1992:51-64.

Helminiak, D A 2006. Sex and the sacred: Gay identity and spiritual growth. Philadelphia, PA: Haworth.

Henry, C F H 2003. The uneasy conscience of modern fundamentalism. Cambridge: William B Eerdmans.

Houlden, $J \mathrm{~L}$ (ed) 1995. The interpretation of the Bible in the church. London: SCM.

Kairos Theologians 1986. The Kairos document: Challenge to the church. Skotaville: Braamfontein.

Kirkpatrick, L A 1993. Fundamentalism, Christian orthodoxy, and intrinsic religious orientation as predictors of discriminatory attitudes. JSSR 32(3), 256-268.

Labuschagné, C J 2000. Zin en onzin rond de bijbel: Bijgeloof, bijbelwtenschap en bijbelgebruik. Zoetermeer: Uitgeverij Boekencentrum.

Laythe, B et al 2001. Religious fundamentalism as a predictor of prejudice: A twocomponent model. JSSR 40(14), 1-10.

Laythe, B et al 2002. Religious fundamentalism as a predictor of prejudice: A twocomponent model. JSSR 41(4), 623-635.

Montsma, J A 1999. Ortodoxie en fundamentalisme, in Montsma 1999:37-46.

Montsma, J A, Schuman, N A \& de Wit, J H (reds) 1999. Fundamentalisme: Tussen afkeer en herkenning. Zoetermeer: Uitgeverij Meinema. (VU-segmenten 6.)

Malina, B J 2001. The social gospel of Jesus :The kingdom of God in Mediterranean perspective. Minneapolis, MN: Fortress.

Malina, B J \& Rohrbaugh, R L 1992. Social science commentary on the Synoptic Gospels. Minneapolis, MN: Fortress.

Marsden, G M 21991. Understanding fundamentalism and evangelicalism. Grand Rapids, MI: William B Eerdmans. 
Marsden, G M 2006. Fundamentalism and American culture. Oxford: Oxford University Press.

McKim, D K (ed). 1998. Historical handbook of major Biblical interpreters. Downers Grove, IL: InterVarsity Press.

Nagata, J 2004. Beyond theology: Toward an anthropology of "fundamentalism". American Anthropologist 103(2), 481-498.

NHKA 2004. Die Bybel - God se Woord ook vir ons tyd: Gedagtes oor die Kerk se Skrifbeskouing. Notule van die 66ste Algemene Kerkvergadering.

Nicole, R 1992. John Calvin and inerrancy, in Gamble 1992:273-290.

Peek, C W, Lowe, G D \& Williams, L S 1990. Gender and God's word: Another look at religious fundamentalism and sexism. Social Forces 69, 1205-1219.

Pelser, G M M 1988. Die kanon in die kanon as hermeneuties-teologiese probleem. HTS 44(2), 388-403.

Puckett, D L 1998. Calvin, John (1509-1564), in McKim (1998:171-179).

Rowatta; W C \& Franklin, L M 2004. Christian orthodoxy, religious fundamentalism, and right-wing authoritarianism as predictors of implicit racial prejudice. International Journal for the Psychology of Religion 14(2) 125-128.

Ruthven, M 2004. Fundamentalism: The search for meaning. Oxford: Oxford University Press.

Schwartz, J P \& Lindley, L D 2005. Religious fundamentalism and attachment: prediction of homophobia. International Journal for the Psychology of Religion 15(2), 145-157.

Scott, B B 2001. Re-imagine the world: An introduction to the parables of Jesus. Santa Rosa, CA: Polebridge.

Smit, D J 2006. Neem, lees! Hoe ons die Bybel hoor en verstaan. Paarl: Lux Verbi BM.

Snyman, G 2007. Bybellees bring verantwoordelikheid. Ongepubliseerde publikasie. UNISA.

Spong, J S 1991. Rescuing the Bible from fundamentalism: A bishop rethinks the meaning of Scripture. New York: HarperCollins.

Thiselton, A C 2007. The hermeneutics of doctrine. Cambridge: William B Eerdmans.

Torrance, D w \& Torrance, T F (eds) 1963. Calvin's commentaries - Hebrews and 1 \& 2 Peter, tr by W B Johnstone. Michigan, MI: William B Eerdmans.

Van Aarde, A G 1981. Kritiek op die fundamentalisme: 'n Vorm van teologiese liberalisme? HTS 37(4), 6-21.

Van Aarde, A G 2005. Teologiese hermeneutiek. Ongepubliseerde lesingaantekeninge vir OTW 451. Universiteit van Pretoria, Pretoria.

Van Aarde, A G 2008. Fondamentalisme en Skrifbeskouing - 'n teoretiese besinning. Ongepubliseerde voordrag, Voortgesette Teologiese Toerusting, Hervormde Teologiese Kollege, Universiteit van Pretoria.

Van Eck, E 1986a. Die Kairos-dokument: wat sê dit? Die Hervormer, September 1986, bl 12-13.

Van Eck, E 1986b. Die Kairos-dokument (2): Marxisties of nie? Die Hervormer, Oktober 196, bl 6.

Van Eck, E 1986c. Die Kairos-dokument (3): 'n Moontlike antwoord. Die Hervormer Desember 1986, bl 11.

Van Eck, E 2007a. Die huwelik in die eerste-eeuse Mediterreense wêreld (I): Vroue in 'n man se wêreld. HTS 63(1), 81-101. 
Van Eck, E 2007b. Die huwelik in die eerste-eeuse Mediterreense wêreld (II): Huwelik, egbreuk, egskeiding en hertrou. HTS 63(1), 103-128.

Van Eck, E 2007c. Die huwelik in die eerste-eeuse Mediterreense wêreld (III): Jesus en die huwelik. HTS 63(2), 481-513.

Van Harskamp, A 1999. De tegen-wereld van het christelijke fundamentalisme, in Montsma (1999:11-36).

Village, A 2007. The Bible and lay people: An empirical approach to ordinary hermeneutics. Burlington, VT: Ashgate.

West, G 2008. Thabo Mbeki's Bible: The role of religion in the South African public realm after liberation. Online: http://www. sbl-site/publications/article.aspx? articleld $=770$. 